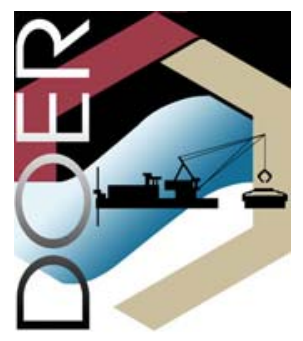

ERDC TN-DOER-R15

April 2011

\title{
Development of a Bioaccumulation Test Method with the Amphipod Leptocheirus plumulosus
}

\author{
by J. Daniel Farrar, Guilherme Lotufo, and Jerre Sims
}

PURPOSE: This technical note provides information on the procedures and approach utilized in the development of a bioaccumulation test method using the amphipod Leptocheirus plumulosus.

BACKGROUND: Dredged material evaluations routinely require the use of sediment bioaccumulation tests to determine the potential for sediment-borne contaminants to bioaccumulate and to evaluate the risk posed to higher trophic levels. Marine/estuarine bioaccumulation test species include field-collected Macoma nasuta and Nereis virens, as well as other less frequently used bivalves and polychaetes. Utilizing field-collected organisms in bioaccumulation tests is problematic. Field-collected organisms may be subject to seasonal availability (e.g., available in the summer but not in the winter). They may also display varying levels of responsiveness (e.g., survival, variation in uptake rates, etc.) due to temporal changes in the field such as natural or anthropogenic background contaminant exposure (American Society for Testing and Materials (ASTM) 2007). Laboratory cultured organisms, such as Leptocheirus plumulosus, are reared in a controlled environment where environmental conditions are closely controlled and monitored, eliminating many of the issues associated with the use of field-collected organisms. The time required to reach steady state is also a concern with some species. Steady-state body residues of most hydrophobic organic compounds (HOCs) of concern in M. nasuta are typically approached many weeks beyond the standard 28-day duration of sediment bioaccumulation tests (Boese et al. 1997). The failure to reach steady state within the standard 28 -day time frame requires an estimation of steady-state residues using conversion factors which introduce uncertainty into bioaccumulation estimates (U.S. Environmental Protection Agency (USEPA) and U.S. Army Corps of Engineers (USACE) 1998). The metabolic disposition of contaminants in an organism is also important when selecting a bioaccumulation test species. $N$. virens and other polychaetes biotransform PAHs efficiently and therefore are poor indicators of the bioaccumulation potential of these compounds (McElroy 1990; Driscoll and McElroy 1996; Jorgensen et al. 2005).

Recently developed micro methods for tissue analysis require much less tissue mass compared to traditional tests while providing comparable detection limits (Jones et al. 2006; Millward et al. 2007). A smaller mass requirement allows for the exploration of the use of smaller invertebrate species, such as L. plumulosus (Figure 1), for use in sediment bioaccumulation tests. L. plumulosus is routinely used as a model organism for conducting acute and chronic sediment toxicity tests (USEPA 1994; 2001). It is easily cultured and is readily available from aquatic test organism vendors. Preliminary experiments conducted at the ERDC using sediment-spiked compounds revealed that $L$. plumulosus bioaccumulates HOCs at steady-state concentrations during short sediment exposures (i.e., one week or shorter) and inefficiently metabolizes PAHs. These attributes warrant the development of a standard bioaccumulation test method for use with this 
species. Additionally, the feasibility of utilizing amphipods for evaluating bioaccumulation potential has been established by researchers who have used them for evaluating PCB body burdens in both the laboratory and the field setting (Millward et al. 2005; Cho et al. 2007). The availability of a bioaccumulation test method using L. plumulosus would result in improved evaluation of dredged material bioaccumulation potential compared to current available methodology due to reduced sediment and labor requirements and improved predictive value resulting from elimination of uncertainties associated with deriving steady-state body residues using multipliers and loss due to efficient biotransformation.

OBJECTIVES: The specific objective of this study was to develop a 28-day bioaccumulation test method with L. plumulosus by evaluating various test parameters to determine the optimum test or exposure conditions in a controlled environment. Variables were evaluated concurrently to determine the optimum level of each that results in the highest survival and mass (i.e., meeting or exceeding minimum analytical requirements) at test termination. High survival and tissue mass at the end of sediment exposure are the principle objectives in bioaccumulation test method development since the primary endpoint is measurement of tissue residue levels. High quality chemical residue analysis requires the maximum amount of

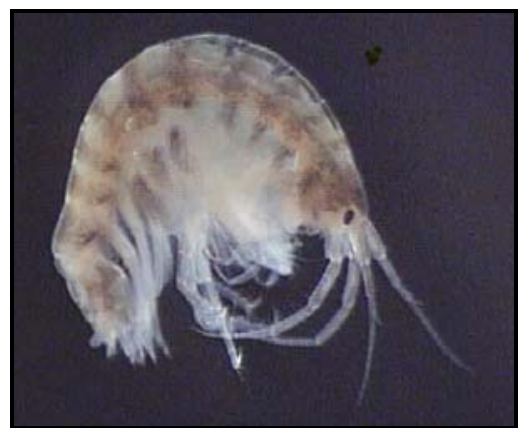

Figure 1. The estuarine amphipod Leptocheirus plumulosus. tissue recovery that can be obtained.

METHODS: Parameters evaluated as part of the test method development process included two levels of organism density, water exchange frequency, and ration level. Specifically, treatment levels included starting densities of 25 or 50 organisms per chamber, once weekly or three times weekly water renewal, and no feeding and feeding (20 mg of Tetramarin ${ }^{\circledR}$ fish food per beaker on Tuesdays and Fridays). The food ration level selected was based on results obtained in previous preliminary studies conducted at the ERDC. This feeding level demonstrated good survival with no fouling of the sediment surface. Treatment levels were designated as follows:

\begin{tabular}{|c|c|c|c|}
\hline \multicolumn{4}{|c|}{ Nomenclature: Density-water exchange frequency-feeding regime (1=fed; 0 = not fed $)$} \\
\hline $25-1-0$ & $25-3-0$ & $50-1-0$ & $50-3-0$ \\
\hline $25-1-1$ & $25-3-1$ & $50-1-1$ & $50-3-1$ \\
\hline
\end{tabular}

The test method procedures utilized with L. plumulosus are generally similar to the bioaccumulation methods described for $N$. virens and M. nasuta in the ocean and inland testing manuals (USEPA and USACE 1991; 1998). The day prior to test initiation, adult test organisms $(1-2 \mathrm{~mm}$ in size) were isolated from in-house culture sediment by passing the culture sediment through a 2-mm and a 1-mm sieve stack. Organisms retained on the 1-mm sieve were used in the study while organisms retained on the 2-mm sieve and passing through the 1-mm sieve were discarded or returned to culture. Organisms were placed in bowls of clean Instant Ocean ${ }^{\circledR}$ seawater and observed to ensure they were healthy. Once organisms were isolated and their level of health established, $200 \mathrm{~mL}$ (3 cm) of clean control sediment was added to five replicate 1-L beakers for each treatment level. The control sediment was collected from Sequim Bay, WA and contained a 
TOC concentration of $0.64 \%$ with a wet to dry weight ratio of 3 to 1 . Sediment was overlain with 20\%o synthetic seawater (Crystal Sea, Marine Enterprise, Intl., Baltimore, MD) and placed in an environmental chamber. The temperature of the environmental chamber was set at $23^{\circ} \mathrm{C}$ and the light cycle was set at $16 \mathrm{hr}$ light:8 hr dark. Trickle flow aeration was provided to each beaker.

The following day overlying water quality parameters (dissolved oxygen, $\mathrm{pH}$, salinity, and ammonia) were measured on one replicate of each treatment level. Depending on treatment level, 25 or 50 adult L. plumulosus were counted and placed into the appropriate test beakers. Feeding and water exchanges were conducted during the course of the study according to the study design. Fifty percent water exchanges were conducted on Wednesdays for beakers requiring one renewal and on Mondays, Wednesdays, and Fridays for beakers requiring three renewals. Water quality parameters (dissolved oxygen, $\mathrm{pH}$, temperature, and salinity) were measured on Wednesdays prior to water exchange and organisms were fed on Wednesdays following the scheduled water exchange.

At day 28, water quality parameters (dissolved oxygen, $\mathrm{pH}$, temperature, salinity, and ammonia) were measured on the overlying water from each beaker. The sediment from each beaker was then passed through a 500- $\mu \mathrm{m}$ sieve and organisms retained were enumerated and placed in clean seawater and allowed to purge sediment from their guts for approximately $4 \mathrm{hr}$ (Millward et al. 2005). The amphipods were then placed in pre-tared vials for mass determination. Statistical analyses of the survival and growth endpoints within treatment levels were conducted using a t-test with $\alpha=0.05$.

Optimum conditions for the test method were determined by selecting the highest organism density with the lowest number of water exchanges and lowest feeding level that did not result in significant decreases in survival or growth. A high density is desirable to ensure adequate tissue mass for tissue residue analysis. A low water exchange frequency minimizes the loss of contaminants from the exposure system due to the flux of contaminants from the sediment to the overlying water. A low feeding ration level minimizes the expected reduced exposure from the addition of supplementary food and also minimizes the effect of adding additional organic carbon to the exposure system.

Results and Discussion: Test survival and biomass results are summarized in Tables 1 and 2. The effects of density, water exchange frequency, and ration level on survival and growth are presented in Figures 1-6. 
ERDC TN-DOER-R15

April 2011

Table 1. L. plumulosus survival after 28 days.

\begin{tabular}{|l|l|l|l|l|}
\hline Treatment & Mean & STDEV & CV & n \\
\hline Control & $98.0 \%$ & $4.5 \%$ & $4.6 \%$ & 5 \\
\hline $25-1-0$ & $54.4 \%$ & $8.3 \%$ & $15.2 \%$ & 5 \\
\hline $25-1-1$ & $64.0 \%$ & $25.3 \%$ & $39.5 \%$ & 5 \\
\hline $25-3-0$ & $56.0 \%$ & $2.8 \%$ & $5.1 \%$ & 5 \\
\hline $25-3-1$ & $68.0 \%$ & $17.2 \%$ & $25.3 \%$ & 5 \\
\hline $50-1-0$ & $29.6 \%$ & $9.2 \%$ & $31.1 \%$ & 5 \\
\hline $50-1-1$ & $74.4 \%$ & $7.9 \%$ & $10.7 \%$ & 5 \\
\hline $50-3-0$ & $41.6 \%$ & $12.3 \%$ & $29.5 \%$ & 5 \\
\hline $50-3-1$ & $72.8 \%$ & $8.3 \%$ & $11.4 \%$ & 5 \\
\hline
\end{tabular}

Table 2. L. plumulosus total replicate biomass $(\mathrm{mg})$ after 28 days.

\begin{tabular}{|l|l|l|l|l|}
\hline Treatment & Mean & STDEV & CV & $\mathbf{n}$ \\
\hline Control & 170.27 & 20.46 & $12.0 \%$ & 5 \\
\hline $25-1-0$ & 39.68 & 8.15 & $20.5 \%$ & 5 \\
\hline $25-1-1$ & 103.48 & 48.73 & $47.1 \%$ & 5 \\
\hline $25-3-0$ & 40.27 & 5.56 & $13.8 \%$ & 5 \\
\hline $25-3-1$ & 121.77 & 21.69 & $17.8 \%$ & 5 \\
\hline $50-1-0$ & 52.50 & 26.40 & $50.3 \%$ & 5 \\
\hline $50-1-1$ & 197.06 & 19.95 & $10.1 \%$ & 5 \\
\hline $50-3-0$ & 45.82 & 11.23 & $24.5 \%$ & 5 \\
\hline $50-3-1$ & 179.74 & 46.89 & $26.1 \%$ & 5 \\
\hline
\end{tabular}




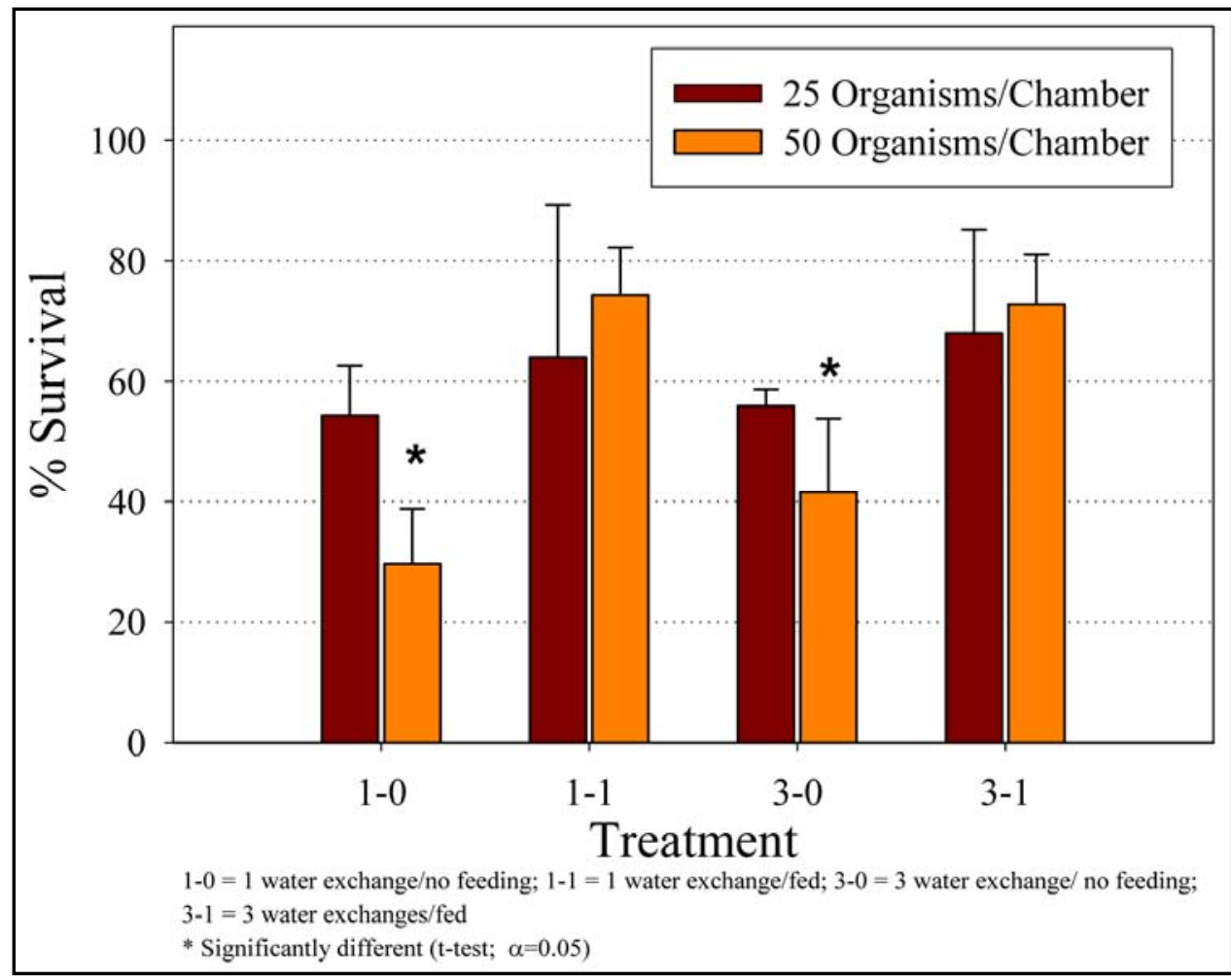

Figure 1. Effect of density on L. plumulosus 28-day survival.

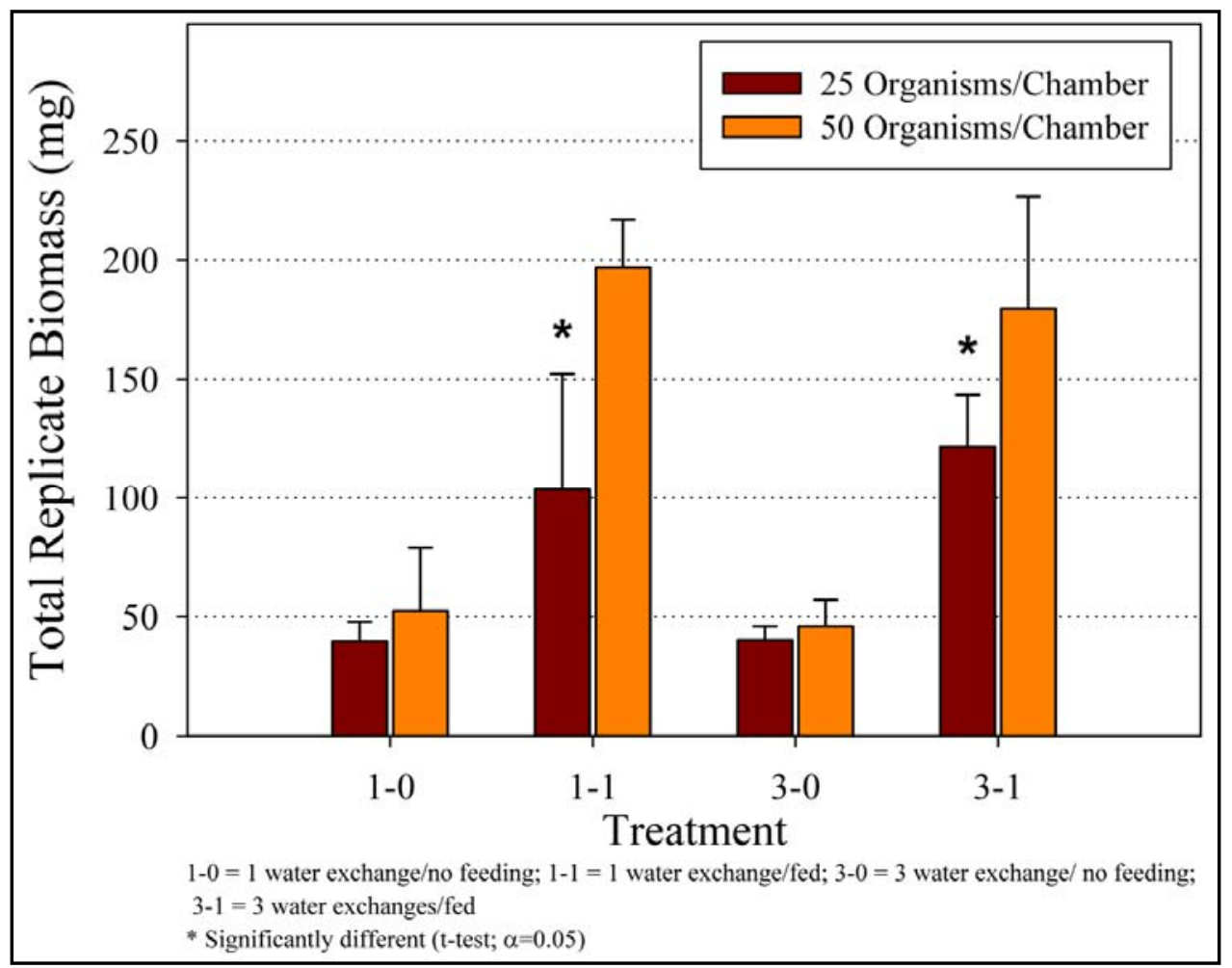

Figure 2. Effect of density on L. plumulosus 28-day growth. 


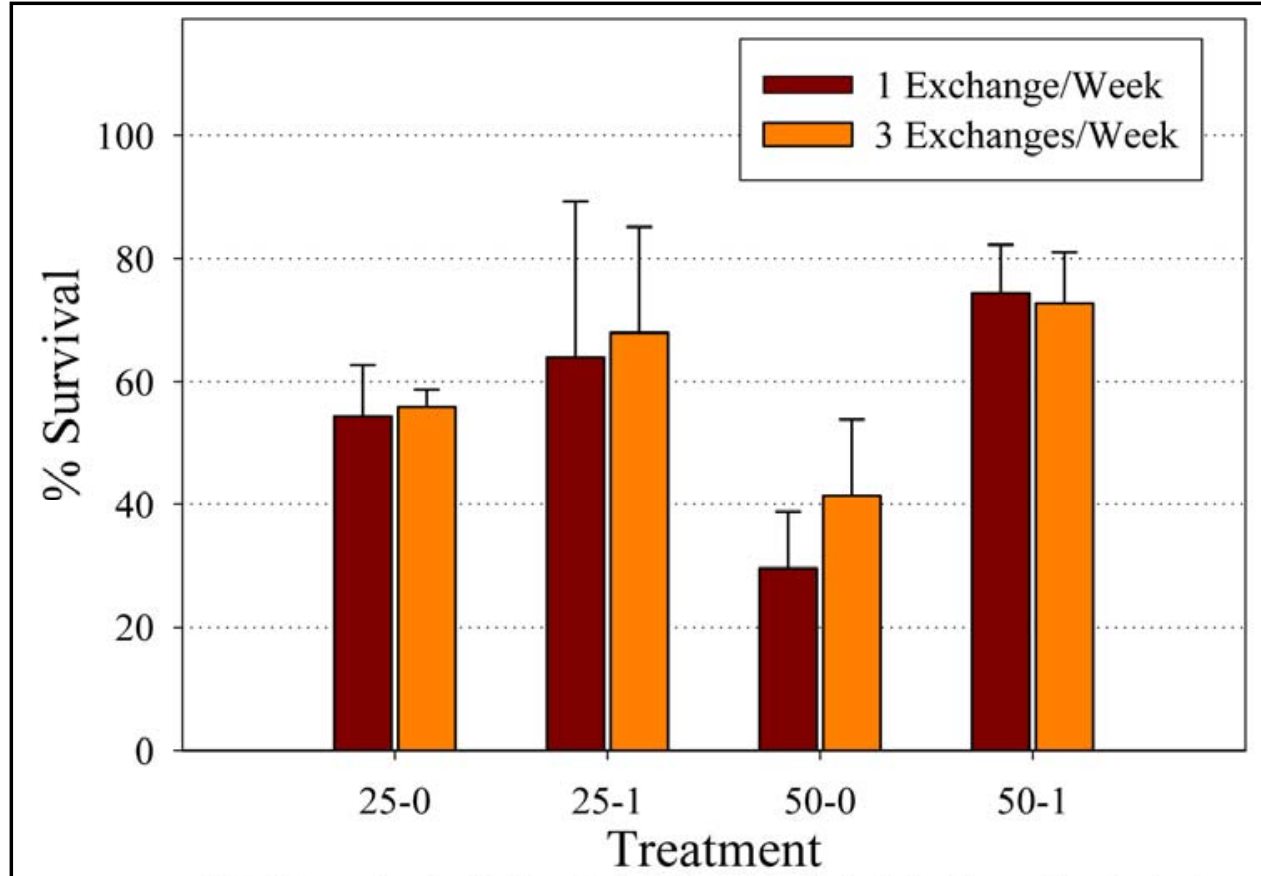

$25-0=25$ organisms/no feeding; $25-1=25$ organisms $/$ fed; $50-0=50$ organisms/no feeding; $50-1=50$ organisms $/$ fed

* Significantly different (t-test; $\alpha=0.05$ )

Figure 3. Effect of water exchange frequency on L. plumulosus 28-day survival.

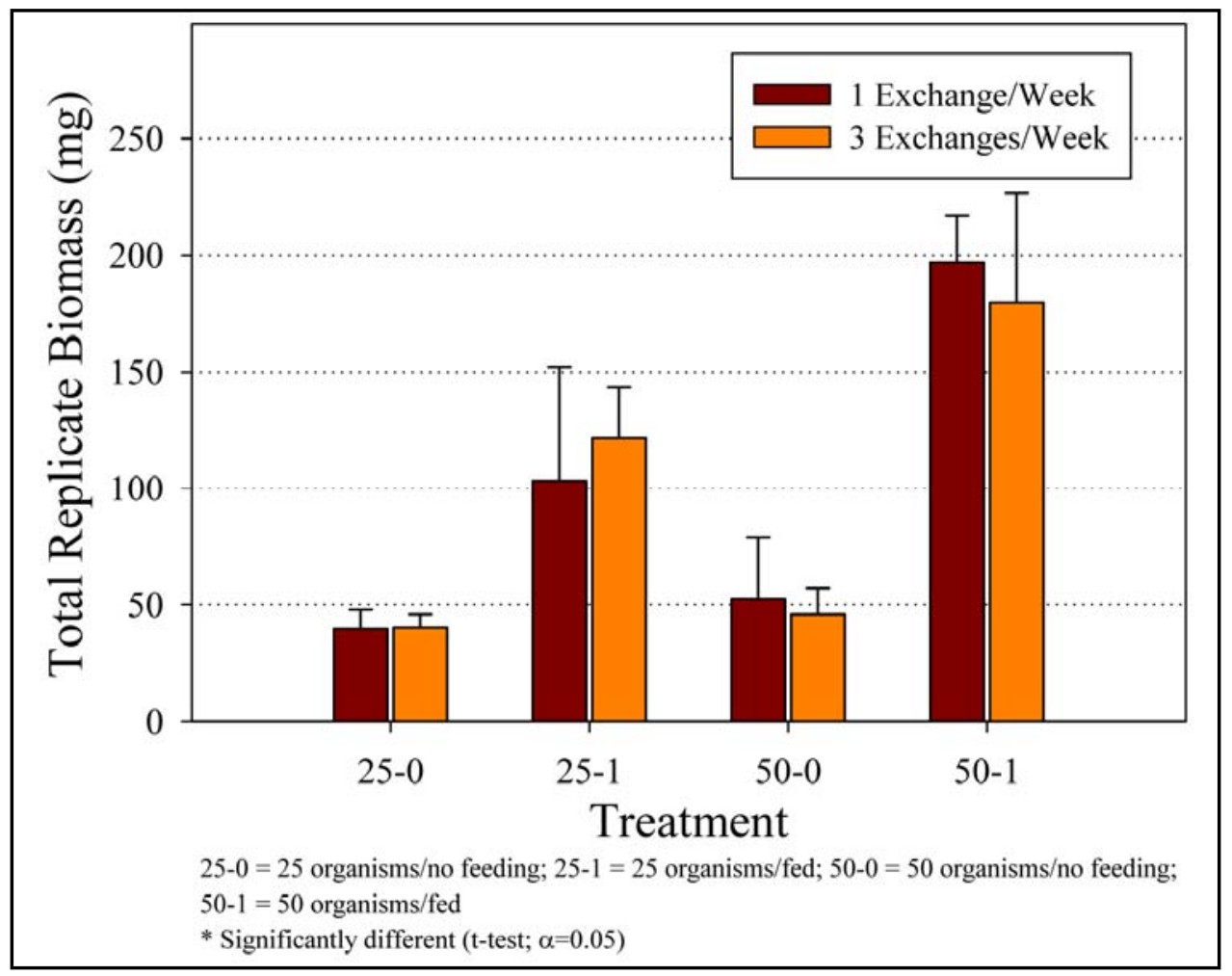

Figure 4. Effect of water exchange frequency on L. plumulosus 28-day growth. 


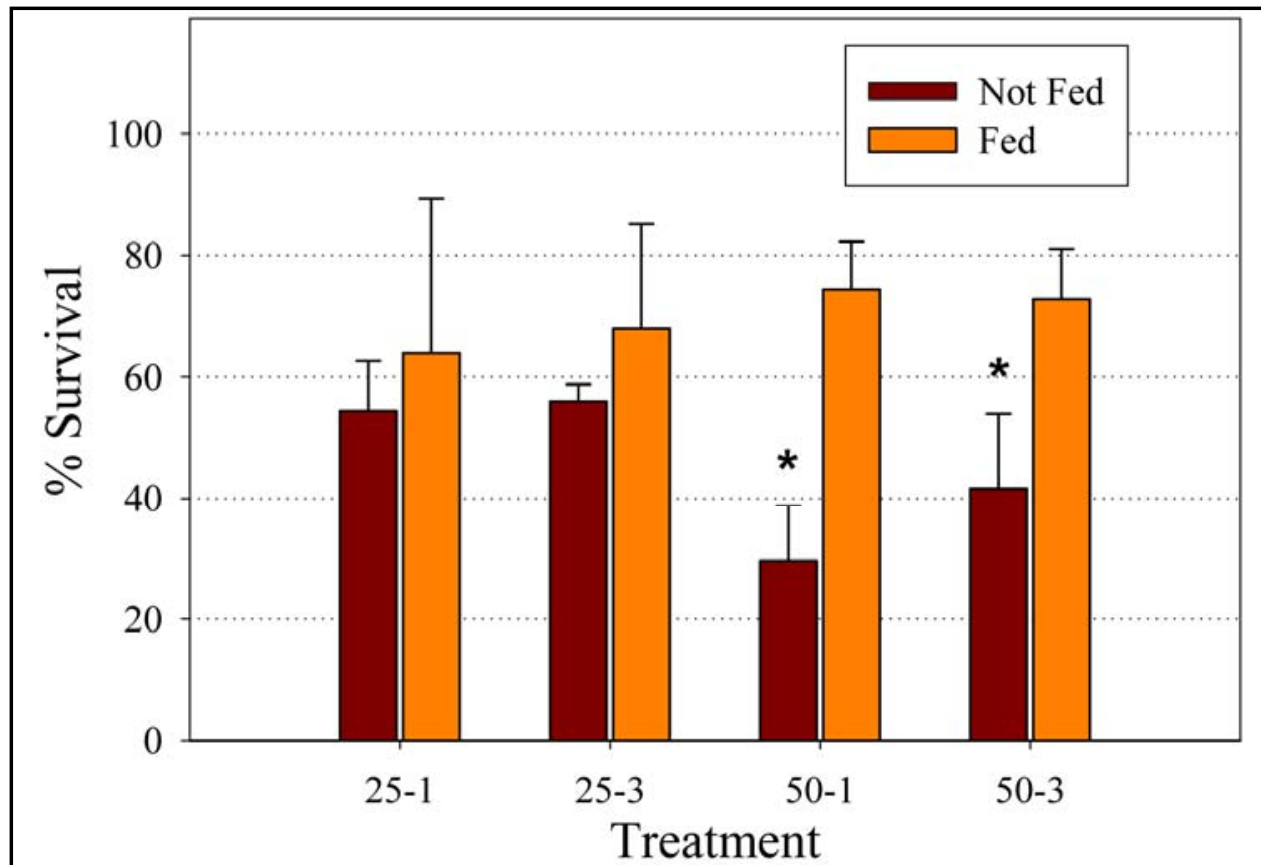

$25-1=25$ organisms $/ 1$ water exchange; $25-3=25$ organisms $/ 3$ water exchanges; $50-1=50$ organisms $/ 1$ water exchange $; 50-3=50$ organisms $/ 3$ water exchanges * Significantly different (t-test; $\alpha=0.05$ )

Figure 5. Effect of ration level on L. plumulosus 28-day survival.

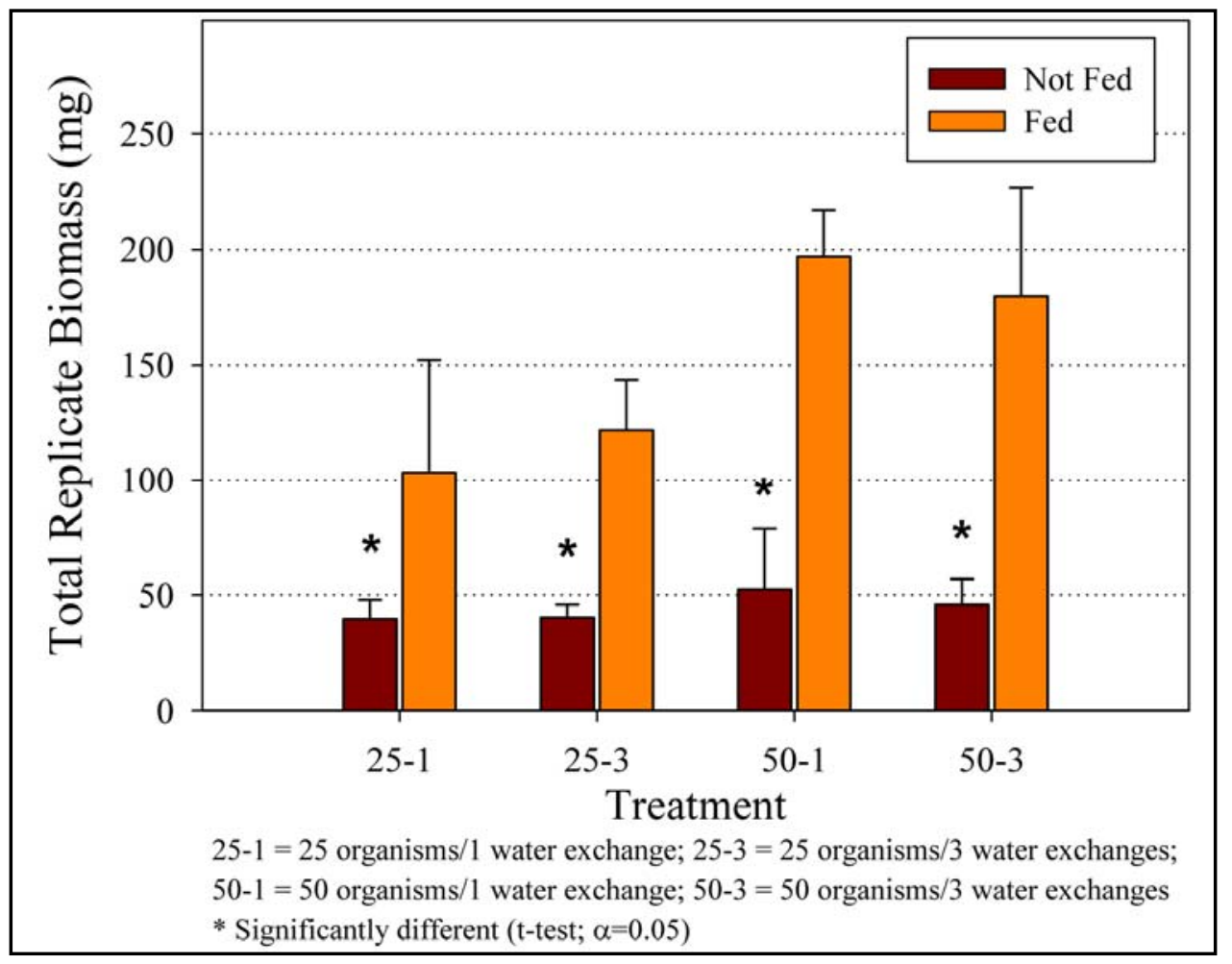

Figure 6. Effect of food ration level on L. plumulosus growth. 
Significant density effects on survival and growth were observed in no-feeding treatments (Figure 1). A significant density effect on growth was observed in the highest density, where water exchanges were conducted three times weekly and the organisms were fed (Figure 2). Water exchange frequency had no effect on survival or growth (Figures 3 and 4). No feeding resulted in significantly lower survival in the high density treatment and lower growth for all treatment combinations (Figures 5 and 6). In summary, the survival and growth endpoints were primarily impacted by feeding levels, which were exacerbated by higher density levels. The only exception was the pure density effect observed in the highest density, where water exchanges were conducted three times weekly and the organisms were fed.

The treatment combination providing optimum survival and growth was a density of 50 organisms per chamber with once-weekly water exchange and twice-weekly feeding. This combination provides tissue mass well exceeding the mass requirements for PAH and PCB micro method analysis (ca $100 \mathrm{mg}$ ). These conditions were selected for further development of the L. plumulosus bioaccumulation test method.

Test conditions proposed for the 28-day bioaccumulation test method with L. plumulosus are summarized in Table 3. A general test activity schedule is provided in Table 4.

\section{Table 3. Test conditions for $L$. plumulosus 28-day sediment bioaccumulation test method.}

\begin{tabular}{|l|l|}
\hline Parameter & Condition \\
\hline Chamber size & 1 Liter beaker \\
\hline Replicates per treatment & 5 \\
\hline Organisms per replicate & 50 \\
\hline Organism size & Passing through a 2-mm sieve and retained on a 1-mm sieve \\
\hline Salinity & $20 \%$ \\
\hline Sediment depth & $3 \mathrm{~cm}(\sim 200 \mathrm{~mL})$ \\
\hline Temperature & $23^{\circ} \mathrm{C}$ \\
\hline Light cycle & $16: 8 \mathrm{~L}: \mathrm{D}$ \\
\hline Water renewal & Once weekly \\
\hline Feeding & 20 mg/chamber twice weekly (Tues and Fri) \\
\hline Aeration & Trickle flow \\
\hline Water Quality Measurements & $\begin{array}{l}\text { Dissolved oxygen, pH, temperature and salinity in one replicate per treatment at test } \\
\text { initiation and all beakers at test breakdown }\end{array}$ \\
\hline
\end{tabular}




\begin{tabular}{|l|l|}
\hline \multicolumn{2}{|l|}{$\begin{array}{l}\text { Table 4. Daily activity schedule for conducting for } L \text {. plumulosus 28-day sediment } \\
\text { bioaccumulation test method. }\end{array}$} \\
\hline Day & Activity \\
\hline-1 & $\begin{array}{l}\text { Isolate amphipods for conducting bioaccumulation test. Add sediment to test chambers, place chambers into } \\
\text { exposure system. }\end{array}$ \\
\hline 0 & $\begin{array}{l}\text { Measure overlying water quality (pH, temperature, salinity, dissolved oxygen and ammonia). Transfer the } \\
\text { appropriate number of amphipods to each exposure chamber. Collect a subset sample of amphipods for } \\
\text { residue analyses. }\end{array}$ \\
\hline $1-27$ & $\begin{array}{l}\text { Observe test organism behavior daily. Record test chamber temperature daily. On Wednesdays measure } \\
\text { overlying water quality (pH temperature and salinity), perform a } 50 \% \text { water exchange and place } 20 \text { mg of } \\
\text { Tetramin® in each replicate test chamber. }\end{array}$ \\
\hline 28 & $\begin{array}{l}\text { Measure overlying water quality (pH, temperature, salinity, dissolved oxygen and ammonia) in each test } \\
\text { chamber. End the study by passing the sediment through a } 500-\mu m \text { sieve and collecting the surviving amphi- } \\
\text { pods. Allow the amphipods to purge their guts for } 2-4 \text { hr. Determine the mass of the surviving amphipods. }\end{array}$ \\
\hline
\end{tabular}

SUMMARY AND RECOMENDATIONS: Evaluation of L. plumulosus as a model organism for determining the bioaccumulation potential of contaminants in dredged material demonstrated the viability of a test method with this organism. The use of L. plumulosus in conjunction with available micro methods for PAHs and PCBs as well as select standard chemistry approaches (e.g., metals) will result in a substantial cost savings due to much lower sediment volume requirements and labor required to conduct the study.

Future work will focus on determining the timeframe required to reach steady state in L. plumulosus, which could result in a decrease in the duration of the test and further cost savings. Future work will also be conducted to compare the bioaccumulative endpoints such as steady-state body residues and biota sediment accumulation factors (BSAFs) between L. plumulosus and the frequently used standard bioaccumulation test methods using $N$. virens and M. nasuta (and other organisms as deemed appropriate) to determine relative responsiveness of the L. plumulosus method as compared to these standard approaches.

ACKNOWLEDGEMENTS: This research was supported by the U.S. Army Corps of Engineers under the Dredging Operations and Environmental Research (DOER) Program. Laboratory support at the ERDC was provided by Jennifer Goss and Jamma Williams.

Disclaimer: Use of trademark materials or equipment does not imply a sole endorsement of these products by the U.S. Army Corps of Engineers. Any equivalent material or equipment can also be utilized.

POINTS OF CONTACT: For additional information, contact the authors, J. Daniel Farrar (601634-2118; Daniel.Farrar@usace.army.mil), Dr. Guilherme Lotufo, (225-298-5481 ext. 3124, Guilherme.Lotufo@usace.army.mil) or the manager of the Dredging Operations and Environmental Research Program, Dr. Todd Bridges (601-634-3626; Todd.S.Bridges@usace.army.mil. This technical note should be cited as follows: 
Farrar, J. D., G. R. Lotufo, and J. G. Sims. 2011. Development of a bioaccumulation test method with the amphipod Leptocheirus plumulosus. DOER Technical Notes Collection. ERDC TN-DOER-R15, Vicksburg, MS: U.S. Army Engineer Research and Development Center.

\section{REFERENCES}

American Society for Testing and Materials (ASTM). 2007. Standard Guide for determination of the bioaccumulation of sediment associated contaminants by benthic invertebrates. ASTM E 1688. ASTM International.

Boese, B. L., H. Lee, and S. Echols. 1997. Evaluation of a first-order model for the prediction of the bioaccumulation of PCBs and DDT from sediment into the marine deposit-feeding clam Macoma nasuta. Environmental Toxicology and Chemistry 16 (7): 1545-1553.

Cho, Y. M., D. W. Smithenry, U. Ghosh, A. J. Kennedy, R. N. Millward, T. S. Bridges, and R. G. Luthy. 2007. Field methods for amending marine sediment with activated carbon and assessing treatment effectiveness. Marine Environmental Research 64 (5): 541-555.

Driscoll, S. K., and A. E. McElroy. 1996. Bioaccumulation and metabolism of benzo[a]pyrene in three species of polychaete worms. Environmental Toxicology and Chemistry 15 (8): 1401-1410.

Jones, R. P., R. N. Millward, R. A. Karn, and A. H. Harrison. 2006. Microscale analytical methods for the quantitative detection of PCBs and PAHs in small tissue masses. Chemosphere 62 (11): 1795-1805.

Jorgensen, A., A. M. B. Giessing, L. J. Rasmussen, and O. Andersen. 2005. Biotransformation of the polycyclic aromatic hydrocarbon pyrene in the marine polychaete Nereis virens. Environmental Toxicology and Chemistry 24 (11): 2796-2805.

McElroy, A. E. 1990. Polycyclic aromatic hydrocarbon metabolism in the polychaete Nereis virens. Aquat. Toxicol. 18 (1): 35-50.

Millward, R. N., T. S. Bridges, U. Ghosh, J. R. Zimmerman, and R. G. Luthy. 2005. Addition of activated carbon to sediments to reduce PCB bioaccumulation by a polychaete (Neanthes arencaceodentata), and an amphipod (Leptocheirus plumulosus). Environ. Sci. Technol. 39 (8): 2880-2887.

Millward, R. N., R. P. Jones, R. A. Karn, and A. H. Harrison. 2007. A microscale approach for the quantitative detection of PCB $s$ and PAHs in small tissue masses. DOER Technical Notes Collection. ERDC TN-DOER-T9. Vicksburg, MS: U.S. Army Engineer Research and Development Center. http://el.erdc.usace.army.mil/dots/ doer/.

U.S. Environmental Protection Agency (USEPA) and U.S. Army Corps of Engineers (USACE). 1991. Evaluation of dredged material proposed for ocean disposal - Testing manual. EPA-503-8-91-001. Washington, DC.

1998. Evaluation of dredged material proposed for discharge in waters of the U.S. - Testing manual. EPA-823-B-98-004. Washington, DC.

U.S. Environmental Protection Agency (USEPA). 1994. Methods for assessing the toxicity of sediment-associated contaminants with estuarine and marine amphipods. EPA-600-R-94-025. Washington, DC.

.2001. Methods for assessing the chronic toxicity of marine and estuarine sediment-associated contaminants with the amphipod Leptocheirus plumulosus. EPA-600-R-01-020. Washington, DC.

NOTE: The contents of this technical note are not to be used for advertising, publication, or promotional purposes. Citation of trade names does not constitute an official endorsement or approval of the use of such products. 